\title{
Women and Legislative Representation in Nigeria's National Assembly: A Detailed Appraisal of the 8th Assembly (2015-2019)
}

\author{
Jake Dabang Dan-Azumi \\ Special Assistant (Technical) to the Director-General, \\ National Institute for Legislative and Democratic Studies (NILDS), \\ National Assembly, Nigeria (Corresponding author)
}

Caroline Asan

Committee Clerk/ Chief legislative officer, House of Representatives, National Assembly, Nigeria

Received: Feb. 11, 2021 Accepted: Apr. 2, 2021 Online published: Apr. 18, 2021

doi:10.5296/jpag.v11i2.18543ＵRL: https://doi.org/10.5296/jpag.v11i2.18543

\begin{abstract}
This study focuses on women legislative representation in Nigeria since the commencement of the Fourth Republic (1999 to 2020). It investigates the low levels of representation of women in the National Assembly and factors that explain this. Results from the study show that the majority of female respondents indicate active interest in politics but are discouraged by factors that include prevailing gender stereotypes, cultural/religious reasons, unfavourable political environment, lack of financial capacity, electoral violence and restrictive party structures and processes amongst others. The bulk of male respondents confirm these structural biases and barriers to women's political participation. In view of these findings, some recommendations offered include implementation of deliberate policies and legislations that target women quotas and affirmative action, elimination of structural barriers to women's participation, reducing the cost of political participation for women, reforming the electoral process, and sustained and systematic gender education.
\end{abstract}

Keywords: women, gender, legislative representation, democracy, parliament, Nigeria, national assembly 


\section{Introduction}

The choices that citizens make in politics and the rights they exercise in choosing their leaders and consequently holding government to account is described as participation. Participation, therefore, often includes forming political associations, voting, taking part in decision-making, holding party or public offices and partaking in other political processes, etc. (Milbrath, 1965). The notion of equal representation is linked to the very concept of democracy and represents both a goal and an ideal. According to the Inter-Parliamentary Union (IPU) (1998), "equal representation is a basic right of citizenship to be exercised under conditions of freedom, equity, transparency and responsibility, with due respect for the plurality of views, and the interest of the polity." By implication, therefore, all adult citizens enjoy equal suffrage, and at no time should a group, gender, etc., be discriminated against in the political process.

Parliaments consist of people who are either duly elected or appointed to represent the people through the performance of core functions that include making laws, providing effective oversight of the executive and ensuring that policies and laws of government are responsive to the needs of the electorate. For a parliament to be 'representative, it should be a miniaturized model or microcosm of society' (Tremblay, 2008, p. 3). As such, strong parliaments encourage and guarantee participation by citizens in political processes. It has been argued that "women are equal citizens and therefore should share, equally with men, public decision-making positions" to avoid 'representation deficit' (Tremblay, 2008). The proportion of women in parliament is seen as an indication of the quality of a state's political representation. Electoral systems affect the proportion of women representation in parliaments. According to Tremblay (2008:7), "legislative assemblies that are denied from a PR system include proportionally twice as many women as parliaments elected through a plurality/ majority system."

Historically, three (3) distinct phases characterise women's engagement in political decision-making. The period between the late $19^{\text {th }}$ and early $20^{\text {th }}$ centuries was largely centred on eliminating cultural inequalities and increasing women's access to education, employment and property ownership. By the early 1900s, there was a more strategic and organised campaign for women's rights through the formation of women's social and political union. This phase saw the rise of feminism, which flourished in the 1940s and 1950s resulting in universal suffrage and equal rights for women. The third phase reflected in the $70 \mathrm{~s}$ occasioned by affirmative action to support women's inclusion in governance by both policy and/or legislation. The United Nations (UN) Conference of 1985 and Beijing Conference of 1995 went further to advocate $30 \%$ women's participation in governance. The fourth phase straddles the third and was launched in 1990 after being shaped by a new and more expansive understanding of gender to include sexual minorities. The World Health Organization (WHO) removed homosexuality from its list of mental disorders in 1990 and rather recognises it as a natural variant of human sexuality. This milestone is annually celebrated as the International Day Against Homophobia, Biphobia and Transphobia (IDAHOBIT). At present, there is momentum towards full political participation and equality for lesbian, gay, bisexual, trans and queer (LGBTQ+). 
According to Paxton \& Hughes (2007), opinions on equal representation for women remain diverse and vary from arguments for more 'formal representation' through the bestowal of rights to women to participate in political leadership as advocated by the Fourth UN World Conference on Women of 1995 to 'descriptive representation' whereby women are guaranteed, at least, $50 \%$ of governmental and decision-making bodies as contested by feminist political philosophers. The third strand of argument centres on 'substantive representation,' which goes beyond numerical representation to including standing for and acting for women's issues and problems.

Participation of women and ethnic minorities in national parliaments has also grown steadily over the past twenty (20) years. However, the literature on LGBTQ+ members of parliament is still evolving (Haider-Markel, 2010; A. Reynolds, 2013). Despite the dearth of cross-national research, Reynolds (2013) states that it is increasingly argued that inclusive legislatures (include those that adequately represent women and recognise sexual orientation diversity) are better at designing stable and just policies (Hartzell \& Hoddie, 2003; Norris, 2008).

Several arguments for greater women participation have been advanced. Delving and Elgie (2008, p. 237) note that whereas there is little evidence that increased women's representation changes policy output, "women add new dimensions to the policy agenda. They cited the Rwandan crisis, which created huge gaps within the male political structure of that country allowing women to make major inroads into politics. Pande and Ford (2011)argue that women are unique in political representation due to certain features including their style of political behaviour. They note that women legislators are mostly engaged with constituency work and problem-solving. There is concordance in the views of Rosenthal (2001), Shevchenko (2002) and Karam and Lovenduski (2005): They suggest that women apply democratic ideals in their leadership and conflict resolution styles and tend to work in a less hierarchical and more collaborative manner than their male colleagues.

Despite limited empirical evidence, there is a growing recognition of the untapped capacity and talents of women and women's leadership (NDI, 2010). An IPU Report (2016) suggests that elections in Europe have resulted in an increase in women's parliamentary representation. The regional average of women across Europe (both houses combined) increased from 25.4 per cent in 2015 to 26.3 per cent ( +0.9 per cent points). This increase has been attributed to "a strong undercurrent of disillusionment with traditional political parties". Ndlovu and Mutale (2013)also argue that despite significant improvement in women in political participation in Africa, the gap in comparison to their male counterparts remains colossal. In Nigeria, however, despite constituting 50\% of the population and playing key roles in election processes particularly grassroots mobilization and campaigns, women remain largely under-represented in both elective and appointive positions as discussed below.

Obstacles to women's political representation have been identified to include socio-cultural factors such as traditional beliefs; negative perception of women in politics; anti-egalitarian practices; religion and patriarchy (Lovenduski \& Norris, 2003); economic limitations such as poverty, poor financial base; institutional and political constraints including electoral systems 
and political party structures(Agishi, 2014; PLAC, 2018). Others are violence; aversion to politics by some women and low self-esteem (Willis, 2014); and lack of support for women politicians both from family members and other institutional structures(Ballington \& Karam, 2005; Karam \& Lovenduski, 2005; Nwabunkeonye, 2014).

This study focuses on women legislative representation in Nigeria since the commencement of the Fourth Republic (1999 to 2020). It investigates the low levels of representation of women in the National Assembly during the period. Results from the study confirm previous research findings which attest to the low rate of women participation in Nigerian politics, particularly in the National Assembly over the last twenty years (Dim \& Asomah, 2019; Ezeani \& Ezeibe, 2013; Norris \& Inglehart, 2001; Obiyan \& Akindele, 2002; Para-Mallam, 2010; Paxton \& Kunovich, 2003; Paxton, Kunovich, \& Hughes, 2007; Andrew Reynolds, 2011; Shola Omotola, 2012). It also confirms the predominant factors that influence women participation, which have not changed significantly despite the government's commitment through a national gender policy and efforts by gender-based Civil Society Organisations (CSOs) and other local and international organisations. In addition to these, whereas several past studies have pointed to the low number of women in the legislature (Tremblay, 2008), very few have focused on assessing the factors that determine and impede women representation in the National Assembly as well as the impact of women's representation on development in Nigeria. The paper makes recommendations on strategies for enhancing women representation in the legislature. Findings from the study will provide useful data on the trend in women representation in Nigeria, particularly at the National Assembly. It will also provide better insight into the obstacles to effective women representation in Nigeria as well as policy recommendations on how to improve women's participation in the legislature.

\section{Trend in Women's Political Representation and Participation in Nigeria}

Nigeria is the most populous country in Africa. The National Bureau of Statistics (NBS) (2016) estimates Nigeria's population to be 193 million people, with women and men constituting 49.2 per cent and 50.8 per cent of this population respectively. Essentially, women constitute about half of Nigeria's population and have played essential roles not only in the family but in political stability and socio-economic development. Historically, women have contributed to both canvassing for human rights and pushing for democratization in pre and post-colonial times (Hamalai, 2014). Women have been integral to both the social, economic and political set up of pre-colonial communities in Nigeria. The prominence of women in decision-making was deliberately downplayed by colonialism when it excluded women from political processes and institutions. However, in 1946, the Richard's Constitution established a House of Chiefs in Northern Nigeria while the other three regions had a House of Assembly and the Macpherson's Constitution established a Regional House of Chiefs in both the North and the West in 1951. Subsequently, three (3) women were appointed into the House of Chiefs in Southern Nigeria. These were Olufunmilayo Ransomekuti (appointed into the Western Nigeria House of Chiefs); Margaret Ekpo and Janet Mokelu (both appointed into the Eastern Nigeria House of Chiefs. Despite the constitutional recognition, they had very little functional powers, as their role was mostly advisory rather than legislative. 
In the immediate post-independence era and Nigeria's First Republic (1963-1966), women's presence and participation remained low. In 1960, Wuraola Esan became the first female member of the Federal Parliament (the Nigerian National Assembly) as a nominated Senator from Ibadan West. In 1961, Margaret Ekpo won a seat in the Eastern Regional House of Assembly and remained a Member until the collapse of the First Republic in 1966.

At the commencement of the Second Republic (1979-1983), few women were elected into the Federal House of Representatives. In 1983, Ms Franca Afegbua was the only woman elected into the Senate of the Federal Republic of Nigeria (Oluyemi, 2016). Similarly, in 1992 while Kofo Bucknor-Akerele won a seat in the Senate, Florence Ita-Giwa won the election into the House of Representatives.

Despite the limited number of women participating in elective politics, Nigeria's history is filled with a rich repository of women activism and involvement not only in politics but in the promotion of human rights, security and peace.

Figure 1. Women's Recent Contributions to Promoting Communal Peace in Nigeria

- The Women Without Walls Initiative in Plateau State, which mobilized a peaceful protest march in March 2010; of about one hundred thousand Christian women within the state came out to lend their voices to put a stop to ethnic conflict;

- Women in Borno State including members of the Women, Peace and Security Network organized a protest against the Shehu of Borno when the attacks in the North East started. They commenced the activism against the abduction of girls from Government Secondary School, Chibok in Borno State. In August 2014, about 300 women and 500 children gathered for two days at the gates of a military base in Maiduguri, the Borno State capital, claiming that their spouses were ill-equipped to fight against the Islamist militants;

- Nasarawa widows, in May 2014, protested peacefully the ambush and murder of their husbands by the "Ombatse Cult" members in Nasarawa State;

- Women staged peaceful protests asking for the release of corpses following the Shiite uprising in Kaduna State. The Sisters Forum of the Islamic Movement of Nigeria staged a peaceful protest to demand the immediate release of their leader, Sheik Ibraheem El- Zakzaky and his wife (2017);

- Women in the Niger Delta have a history of social organizing and activism. Notably, in the 1990s, the Federation of Ogoni Women (FOWA) were at the forefront of the demands for autonomy and control of resources in Ogoni land. By the early 2000s, women in Rivers, Bayelsa and Delta States organized protests and occupations against environmental destruction, lack of development and employment by oil companies such as Shell, Chevron, Elf, Mobil and Agip. In 2002, 600 women from different generations and ethnic groups - Ijaw, Itsekiri and Ilaje - came together in an alliance with young people to peacefully demonstrate against the oil firm, Chevron. The internationally televised sit-ins called on the company to employ youths, invest in the local infrastructure and clean-up up the environmental damage caused by oil exploration. This advocacy highlighted the important role women can play in changing policies in the region; 
and

- Women in the North East and the Niger Delta have often been drawn into political activity as a result of attacks by the Nigerian army's Joint Task Force (JTF) or repeated intimidation by local militias.

Source: UN Women (2018), Program on Women Peace and Security 2018-2020

Nigeria's Fourth Republic began in 1999. Since then, the nation's political space has remained largely dominated by men despite several efforts by both government and non-governmental organisations to enhance women participation and representation in elective politics, particularly in the National Assembly. These efforts include the ratification of the United Nations Convention on the Elimination of all Forms of Discrimination against Women (CEDAW) and the establishment of the National Commission for Women in 1989, which morphed into the Ministry of Women Affairs in 1995. In 2006, Nigeria developed a National Gender Policy (2006), which prescribes 35 per cent affirmative action for women into appointive and elective positions. Other efforts include the establishment of the Women Political Empowerment Office and Nigeria Women Trust Fund (2011) and the 100 Women Lobby Group. Others comprise the development of a gender policy for the Independent National Electoral Commission (INEC), the institution of the National Multi-Stakeholder Dialogue and the convening of the Nigeria Women Strategy Conference (Oluyemi, 2016: 10).

Despite these, very few women are involved in decision-making and resource allocation. A statistical report on women and men in Nigeria shows that representation of high-ranking government officials with decision-making powers is heavily lopsided in favour of men (NBS, 2017).

In 1999, only sixteen (16) women were elected into the National Assembly with thirteen (13) in the House of Representatives and three (3) in the Senate. The total number increased to 25 in 2003 with twenty-one (21) in the House and four (4) in the Senate. The highest number of women ever to be elected into the National Assembly is thirty (36) in 2007 with twenty-seven (27) in the House and nine (9) in the Senate. Since then, there has been a steady decline to thirty-two (32) in 2011, twenty-nine (29) in 2015 and seventeen (17) in 2019.

Globally, the percentage of women occupying legislative positions stands at $42.4 \%$ (Inter-Parliamentary Union, IPU; 2019). Out of 193 countries surveyed, Nigeria occupies the $181^{\text {st }}$ position in the world ranking of women parliamentary representation (IPU, 2019) as shown below.

Table 1. Gender Representation in the Senate and House of Representatives since 1999

\begin{tabular}{|c|c|c|c|c|c|c|c|c|c|c|}
\hline & \multicolumn{4}{|c|}{ Senate } & \multicolumn{4}{c|}{ House of Representatives } \\
\hline Election Year & No of Seats & Men & \% & Women & \% & Seats & Men & \% & Women & \% \\
\hline $\mathbf{1 9 9 9}$ & 109 & 106 & 97.2 & 3 & 2.8 & 360 & 347 & 96.4 & 13 & 3.6 \\
\hline $\mathbf{2 0 0 3}$ & 109 & 105 & 96.3 & 4 & 3.7 & 360 & 339 & 94.2 & 21 & 5.8 \\
\hline $\mathbf{2 0 0 7}$ & 109 & 100 & 91.7 & 9 & 8.3 & 360 & 333 & 92.5 & 27 & 7.5 \\
\hline $\mathbf{2 0 1 1}$ & 109 & 102 & 93.5 & 7 & 6.5 & 360 & 335 & 93.1 & 25 & 6.9 \\
\hline $\mathbf{2 0 1 5}$ & 109 & 102 & 93.5 & 7 & 6.5 & 360 & 338 & 94 & 22 & 6 \\
\hline $\mathbf{2 0 1 9}$ & 109 & 102 & 93.5 & 7 & 6.5 & 360 & 350 & 97.2 & 10 & 2.7 \\
\hline
\end{tabular}


Source: NBS, 2017

The underrepresentation of women in politics is not peculiar to Nigeria. According to the IPU (2015), "the past two decades have witnessed an impressive rise in women's political representation around the world, with the global average in the share of women in national parliaments doubling during that time, and all regions making substantial progress towards the goal of 30 per cent women's representation in decision making."

Nowhere in the world has the rate of increase in the political representation of women been as rapid as in sub-Saharan Africa. In 1995, no African country had elected more than 30 per cent women to its single or lower houses, but by 2015, twelve countries elected more than 30 per cent women to such legislative houses; five elected more than 40 per cent; while one (Rwanda) elected more than 60 per cent. (IPU, 2015: 6).

Data from the Inter-Parliamentary Union (IPU) in 2019 show that the percentage of women representation in Africa surpasses those of some developed regions like North America, Europe and Asia. Rwanda has the highest number of women in the legislature with $61.25 \%$ in the Lower House and $38.46 \%$ in the Upper House. The next is Namibia where women constitute $46.15 \%$ in the Lower House and $23.81 \%$ in the Upper House while South Africa has $42.75 \%$ of women in the Lower House and $35.19 \%$ in the Upper House. Other countries with a significant percentage of women in the legislature include Senegal with $41.82 \%$ women in the unicameral parliament (IPU, 2019).

In addition to the introduction of elective quotas for women, some African governments have also introduced women quota in the cabinet. After the 2019 general elections in South Africa, the President ensured that his cabinet reflected a 50-50 gender representation; similar actions were taken in Ethiopia and Rwanda. Overall, evidence shows that these and other strategies have largely resulted in an increase in the global average of women legislators from 11.6 per cent in 1995 to $24.5 \%$ in 2019.

Despite this progress, the rate of women participation globally is below the 35 per cent recommended for women representation.

Table 2. Percentage of Women in National Parliaments in Sub-Saharan Africa as of December 2018

\begin{tabular}{|l|l|l|l|l|l|l|l|}
\hline \multirow{2}{*}{ Rank } & \multirow{2}{*}{ Country } & \multicolumn{2}{|c|}{ Lower or Single House } & \multicolumn{2}{l|}{ Upper or Senate } \\
\cline { 3 - 8 } & & No of Seats & Women & $\%$ of Women & $\begin{array}{l}\text { No } \\
\text { of Seats }\end{array}$ & Women & $\%$ of Women \\
\hline $\mathbf{1}$ & Rwanda & 80 & 49 & 61.25 & 26 & 10 & 38.46 \\
\hline $\mathbf{7}$ & Namibia & 104 & 48 & 46.15 & 42 & 10 & 23.81 \\
\hline $\mathbf{1 0}$ & South Africa & 393 & 168 & 42.75 & 54 & 19 & 35.19 \\
\hline $\mathbf{1 1}$ & Senegal & 165 & 69 & 41.82 & - & - & - \\
\hline $\mathbf{1 7}$ & Mozambique & 250 & 99 & 39.6 & - & - & - \\
\hline $\mathbf{1 9}$ & Ethiopia & 547 & 212 & 38.76 & 153 & 49 & 32.03 \\
\hline $\mathbf{2 7}$ & Tanzania & 393 & 145 & 36.9 & - & - & - \\
\hline
\end{tabular}




\begin{tabular}{|l|l|l|l|l|l|l|l|}
\hline \multirow{2}{*}{ Rank } & \multirow{2}{*}{ Country } & \multicolumn{2}{|c|}{ Lower or Single House } & \multicolumn{2}{l|}{ Upper or Senate } \\
\cline { 3 - 8 } & & No of Seats & Women & $\%$ of Women & $\begin{array}{l}\text { No } \\
\text { of Seats }\end{array}$ & Women & \% of Women \\
\hline $\mathbf{2 8}$ & Burundi & 121 & 44 & 36.36 & 39 & 18 & 46.15 \\
\hline $\mathbf{2 9}$ & Tunisia & 217 & 78 & 35.94 & - & - & - \\
\hline $\mathbf{3 2}$ & Uganda & 459 & 160 & 34.86 & - & - & - \\
\hline $\mathbf{4 1}$ & Zimbabwe & 270 & 86 & 31.85 & 80 & 35 & 43.15 \\
\hline $\mathbf{4 3}$ & Cameroon & 180 & 56 & 31.11 & - & - & - \\
\hline $\mathbf{4 8}$ & Angola & 220 & 66 & 30 & - & - & - \\
\hline $\mathbf{1 8 1}$ & Nigeria & 109 & 7 & 6.5 & 360 & 22 & 6.1 \\
\hline
\end{tabular}

Source: Adapted from Inter-parliamentary Union's Website (2018) Percentage of Women in National Parliaments

Representation of women in the executive arm of government in Nigeria has equally been very low. There has neither been a woman president nor vice president. In addition, the number of women elected into executive positions at the sub-national level has remained abysmally low. The number of women appointed into ministerial positions has not increased significantly since 1999 as Table 3 shows that it has remained between 5 (in 2015) to the highest number of 15 in 2011.

Table 3. Appointive Ministerial Political Position by Sex (1999 - 2015)

\begin{tabular}{|l|c|c|c|c|c|c|c|c|c|c|c|c|}
\hline \multicolumn{2}{|c|}{1999} & \multicolumn{2}{c|}{2003} & \multicolumn{2}{c|}{2007} & \multicolumn{2}{c|}{2011} & \multicolumn{2}{c|}{$\mathbf{2 0 1 5}$} & \multicolumn{2}{c|}{2019} \\
\hline $\mathbf{M}$ & F & M & F & M & F & M & F & M & F & M & F \\
\hline $\mathbf{8 9}$ & 11 & 38 & 4 & 83 & 12 & 53 & 15 & 31 & 5 & & 7 \\
\hline
\end{tabular}

Source: NBS, 2017

Similarly, very few women have been appointed into top government and senior administrative positions since 1999 as Table 4 shows:

Table 4. Top Government Officials and Senior Administrator, 1999-2015

\begin{tabular}{|l|c|c|c|c|}
\hline Position & M & \% M & F & \% F \\
\hline Head of Service & 9 & 75 & 3 & 25 \\
\hline Permanent Secretary & 95 & 86 & 15 & 14 \\
\hline Special Adviser & 27 & 77 & 8 & 23 \\
\hline Special Assistant & 98 & 72 & 38 & 28 \\
\hline Central Bank Governors & 4 & 100 & 0 & 0 \\
\hline Chief Executive Officer & 307 & 87 & 44 & 13 \\
\hline Director General & 114 & 90 & 12 & 10 \\
\hline Executive Secretary & 29 & 78 & 8 & 22 \\
\hline
\end{tabular}

Source: NBS, 2017 
The level of participation of women in the Judiciary has also been very low as Table 5 shows the number of women judges in federal courts from 2011 to 2016.

Table 5. Number of Judges in Federal Court-by-Court, Year and Sex

\begin{tabular}{|c|c|c|c|c|c|c|c|c|c|c|c|c|}
\hline \multirow[t]{2}{*}{ Court } & \multicolumn{2}{|c|}{2011} & \multicolumn{2}{|c|}{2012} & \multicolumn{2}{|c|}{2013} & \multicolumn{2}{|c|}{2014} & \multicolumn{2}{|c|}{2015} & \multicolumn{2}{|c|}{2016} \\
\hline & $\mathbf{M}$ & $\mathbf{F}$ & $\mathbf{M}$ & $\mathbf{F}$ & $\mathbf{M}$ & $\mathbf{F}$ & $\mathbf{M}$ & $\mathbf{F}$ & M & $\mathbf{F}$ & $\mathbf{M}$ & $\mathbf{F}$ \\
\hline Supreme Court of Nigeria & 11 & 3 & 13 & 3 & 13 & 3 & 13 & 3 & 14 & 3 & 11 & 4 \\
\hline Court of Appeal & 48 & 17 & 52 & 19 & 49 & 17 & 63 & 25 & 61 & 26 & 53 & 26 \\
\hline Federal High Court & 43 & 16 & 40 & 15 & 45 & 20 & 38 & 17 & 36 & 17 & 57 & 23 \\
\hline National Industrial Court & 5 & 3 & 5 & 3 & 11 & 9 & 11 & 9 & 11 & 8 & 11 & 8 \\
\hline
\end{tabular}

Source: NBS, 2017

Many reasons have been advanced for the low level of women participation in elective politics such as an unfavourable political system that makes it difficult for women to fully participate. Some of the barriers facing women include cultural and socio-economic barriers, lower levels of female employment and education, corrupt and patronage-based political system, electoral violence, etc.

\section{Methodology}

This study uses a combination of quantitative and qualitative research designs to improve the reliability and validity of data. Quantitative research design is suitable especially when applied to a larger population and gathering of quantifiable data, qualitative methods provide descriptive data to stated research problems. The choice of a qualitative methodology is based on the complex nature of gender within the context of Nigeria and how it is influenced by other societal factors that include culture, religion, education, etc. Similar, this method can assist in understanding the reciprocal processes through which assumptions about gender are made and how these become institutionalised and part of broader structures of society including democratic institutions.

Both primary and secondary data are also used in the study. Primary data were collected using a questionnaire, in-depth interviews and through attendance of legislative plenary and following of chamber proceedings while secondary data were sourced from journals, publications of the Rules and Business Committee and Tables Department of the House of Representatives, books, newspapers, government records and publications, other online resources, etc. The use of questionnaire was due to their practicability, scalability and ease of analysis while in-depth interviews were used to generate deeper and richer insights.

The target population in the study include legislators serving in the $8^{\text {th }}$ Assembly and staff (2015-2019) as well as selected women and men of voting age, who are literate and possess knowledge of political issues both in Nigeria and globally and conversant with the variables in the study. The purposive sampling technique was adopted for this study. This non-random technique does not require underlying theories or a set number of informants. It implies that "a researcher decides what needs to be known and sets out to find people who can and are willing to provide the information by virtue of their knowledge or experience" (Bernard, 
2002: 33). Using this method, legislators and staff of the National Assembly were targeted. They include Senators, Members of the House of Representatives, parliamentary staff, legislative aides and visitors to the parliament. Those targeted outside the National Assembly include Nigerians from within and the diaspora including politicians, policymakers, academics and business-persons and entrepreneurs.

Questionnaires were administered to respondents from within the National Assembly (legislators and staff) and other respondents in Nigeria and the diaspora who do not necessarily work with the parliament. However, interviews were restricted to only serving members of the $8^{\text {th }}$ Assembly due to their availability and easy accessibility. Past lawmakers that were contacted declined to be interviewed. For Nigerians in the diaspora, questionnaires were sent electronically.

In all, 120 questionnaires were administered to purposefully selected respondents; 80 in the House of Representatives and the Senate; 40 to Abuja residents; and another 40 sent out via e-mail to purposively selected respondents living in Enugu, Kano, Kaduna, Lagos, Makurdi, Port- Harcourt, the United Kingdom and Saudi Arabia. Of the 120 questionnaires administered, 100 questionnaires were returned (32 of those sent via mail and 68 received in hard copies). In-depth interviews were held with four (4) male and four (4) female members of the National Assembly, this was largely informed by the availability of legislators, particularly female lawmakers. Separate questionnaires were administered to male and female respondents in line with the research design and objectives, i.e., to elicit perceptions of the two groups on the issue of women representation and political participation.

Quantitative primary data collected were analysed using the Statistical Package for the Social Sciences (SPSS) while content analysis was used to analyse qualitative data.

\section{Results and Discussions}

\section{Demographics Information}

Table 6 shows the distribution of respondents by gender. $52 \%$ of those that filled and returned the questionnaire were females while $48 \%$ were males.

Table 6. Distribution of Respondents by Gender

\begin{tabular}{|l|c|c|c|c|}
\hline & Frequency & Percent & Valid Percent & Cumulative Percent \\
\hline MALE & 48 & 48.0 & 48.0 & 48.0 \\
\hline FEMALE & 52 & 52.0 & 52.0 & 100.0 \\
\hline Total & 100 & 100.0 & 100.0 & \\
\hline
\end{tabular}

Source: Field Survey (2019)

When disaggregated by age, $14.0 \%$ of the respondents were aged between 18-28 years, $22.0 \%$ were between the ages of 29-39 years, while the bulk of respondents $(64.0 \%)$ were 40 years and above. In general, many of those active in the political space in Nigeria belong to this latter age bracket. Politics, for the most part, has been considered a 'game' of the 'old' or 
'aged' in Nigeria. Recent attempts to change this perception and ensure greater participation of young people in politics led to the 'not-too-young-to-vote' movement, which resulted in a constitutional alteration in 2018 to lower the age of candidates seeking various elective offices in Nigeria. Sections 65, 106, 131 and 171 of the 1999 Constitution were altered to reduce the age qualification for president from 40 to 30; governor from 35 to 30; senator from 35 to 30; Member of the House of Representatives from 30 to 25 and Member of the State House of Assembly from 30 to 25.

Table 7. Distribution of Respondents by Age

\begin{tabular}{|l|c|c|c|c|}
\hline & Frequency & Percent & Valid Percent & Cumulative Percent \\
\hline $18-28$ & 14 & 14.0 & 14.0 & 14.0 \\
\hline $29-39$ & 22 & 22.0 & 22.0 & 36.0 \\
\hline 40 and above & 64 & 64.0 & 64.0 & 100.0 \\
\hline Total & 100 & 100.0 & 100.0 & \\
\hline
\end{tabular}

Source: Field Survey (2019)

One of the key determinants in selecting respondents is educational qualification and knowledge of politics. Table 8 shows that $4.0 \%$ of the respondents had a school certificate, $3.0 \%$ had an Ordinary National Diploma (OND) while 4.0\% had Higher National Diploma (HND). The bulk of respondents $(40.0 \%)$ had a first degree or its equivalent while another $31.0 \%$ had a postgraduate degree or its equivalent. $11.0 \%$ had $\mathrm{PhD}$ qualifications while $6.0 \%$ had a Post Graduate Diploma.

Table 8. Distribution of Respondents by Level of Education

\begin{tabular}{|l|c|c|c|c|}
\hline & Frequency & Percent & Valid Percent & $\begin{array}{c}\text { Cumulative } \\
\text { Percent }\end{array}$ \\
\hline School Certificate & 4 & 4.0 & 4.0 & 4.0 \\
\hline OND & 3 & 3.0 & 3.0 & 7.1 \\
\hline HND & 4 & 4.0 & 4.0 & 11.1 \\
\hline LLB/BSC/BENG/BED & 40 & 40.0 & 40.4 & 51.5 \\
\hline PG Diploma & 6 & 6.0 & 6.1 & 57.6 \\
\hline LLM/MSC/MBA/MA/MPHIL & 31 & 31.0 & 31.3 & 88.9 \\
\hline PhD & 11 & 11.0 & 11.1 & 100.0 \\
\hline Total & 99 & 99.0 & 100.0 & \\
\hline
\end{tabular}

Source: Field Survey (2019)

\section{Respondents' Views}

The majority of respondents (92.9\%) strongly agree that the legislature has a critical role to play in national development particularly in the area of policy decision-making and lawmaking that could affect women. Those interviewed also upheld this position. It confirms the widely held notion that the legislature is perhaps the most important institution of democracy and could influence pro-poor, minority, gender-sensitive and environmental 
policies that spur national development with women at the centre of it.

Table 9. View on Role of the Legislature in National Development

\begin{tabular}{|l|l|c|c|c|c|}
\hline Variables & & Frequency & Percent & Valid Percent & Cumulative Percent \\
\hline \multirow{5}{*}{ Valid } & YES & 91 & 91.0 & 92.9 & 92.9 \\
\cline { 2 - 6 } & NO & 4 & 4.0 & 4.1 & 96.9 \\
\cline { 2 - 6 } & CAN'T SAY & 3 & 3.0 & 3.1 & 100.0 \\
\hline \multirow{3}{*}{ Total } & & 98 & 98.0 & 100.0 & \\
\hline
\end{tabular}

Source: Field Survey (2019)

Of the 52 female respondents, 39 (76.5\%) admit to having an active interest in elective politics and only $11(21.6 \%)$ indicate having no interest. This affirms the widely accepted view that women in Nigeria play a vital role in Nigerian politics as mobilizers, political party leaders, opinion moulders and influencers among other roles. Despite this high level of interest and involvement, very few women actually occupy both elective and appointive positions in Nigeria. These contrasts to some studies that show that women can, sometimes, be averse to politics for various reasons including socio-cultural and economic factors (Willis, 2014 and Novak, 2019).

Table 10. Interest in Elective Politics by Women Respondents

\begin{tabular}{|l|l|c|c|c|c|}
\hline Variables & & Frequency & Percent & Valid Percent & Cumulative Percent \\
\hline \multirow{5}{*}{ Valid } & YES & 39 & 39.0 & 76.5 & 76.5 \\
\cline { 2 - 6 } & NO & 11 & 11.0 & 21.6 & 98.0 \\
\cline { 2 - 6 } & $\begin{array}{l}\text { CAN'T } \\
\text { SAY }\end{array}$ & 1 & 1.0 & 2.0 & 100.0 \\
\hline \multirow{3}{*}{ Total } & 51 & 51.0 & 100.0 & \\
\hline
\end{tabular}

Source: Field Survey (2019)

Despite the interest in politics by female respondents as Table 10 shows, only 7 (13.0\%) of the 52 surveyed have actually participated in elective politics by seeking an elective position while the bulk of the respondents $44(86.3 \%)$ have not sought an elective position in the past.

Table 11. Participation in Elective Politics

\begin{tabular}{|l|l|c|c|c|c|}
\hline Variables & & Frequency & Percent & Valid Percent & Cumulative Percent \\
\hline \multirow{2}{*}{ Valid } & YES & 7 & 7.0 & 13.7 & 13.7 \\
\cline { 2 - 6 } & NO & 44 & 44.0 & 86.3 & 100.0 \\
\hline \multirow{3}{*}{ Total } & 51 & 51.0 & 100.0 & \\
\hline
\end{tabular}

Source: Field Survey (2019)

This finding is in line with several extant studies showing that despite constituting the mass 
of voters and the interest they show in politics and democratic processes, women in Nigeria hardly present themselves as candidates for elections for several reasons ranging from socio-cultural/religious (e.g., gender stereotypes) to economic (e.g., poverty) (Willis, 2014).

Despite the limited number of female respondents who have participated in elective politics, $24(48.0 \%)$ indicate their willingness to seek elective positions, $11(22.0 \%)$ show no interest at all while15 $(30.0 \%)$ were undecided as shown in Table 12. In general, therefore, the willingness of women to fully participate in a women-friendly political environment is sufficiently explored in the literature (Delvin and Elgie, 2003).

Table 12. Interested in Seeking Elective Position

\begin{tabular}{|l|l|c|c|c|c|}
\hline Variables & & Frequency & Percent & Valid Percent & Cumulative Percent \\
\hline \multirow{4}{*}{ Valid } & YES & 24 & 24.0 & 48.0 & 48.0 \\
\cline { 2 - 6 } & NO & 11 & 11.0 & 22.0 & 70.0 \\
\cline { 2 - 6 } & CAN'T SAY & 15 & 15.0 & 30.0 & 100.0 \\
\hline \multicolumn{2}{r}{ Total } & 50 & 50.0 & 100.0 & \\
\hline
\end{tabular}

Source: Field Survey (2019)

Respondents in this study identify various constraints to women's participation in elective politics. These include gender bias (34.1\%), cultural/religious reasons $(35.2 \%)$, lack of funding $(24.1 \%)$, discrimination $(3.3 \%)$, age restrictions $(1.1 \%)$, do/die nature of politics $(1.1 \%)$, and legal limitations $(1.1 \%)$. Overall, respondents identify socio-cultural and religious factors and the resulting gender bias as the main constraints to greater political participation of women in elective politics. This is closely followed by financial constraints as evidenced in the high cost of nomination forms and election campaigns in Nigeria which often automatically excludes women, many of whom are either not working at all (full-time housewives) or involved in subsistence agriculture or other low-paying jobs/occupations.

Table 13. Constraints to Women's Participation in Elective Politics

\begin{tabular}{|c|c|c|c|c|}
\hline Variables & Frequency & \% & Valid \% & Cumulative \% \\
\hline Money & 13 & 24.1 & 24.1 & 24.1 \\
\hline Gender & 16 & 34.1 & 34.1 & 58.2 \\
\hline Age & 1 & 1.1 & 1.1 & 59.3 \\
\hline Cultural/Religious reasons & 18 & 35.3 & 35.2 & 94.5 \\
\hline Legal limitations & 1 & 1.1 & 1.1 & 95.6 \\
\hline Politics as a Zero-Sum game (do or die) & 1 & 1.1 & 1.1 & 96.7 \\
\hline Discrimination & 2 & 3.3 & 3.3 & 100.0 \\
\hline Total & 52 & 100 & 100 & \\
\hline
\end{tabular}

Source: Field Survey (2019)

One of the female legislators interviewed supported the argument that some of the reasons for the limited participation of women in elective politics include cultural/traditional and religious beliefs that limit the role of women to that of domestic caregivers. Other factors 
identified for limited participation by the respondent include lack of requisite finances to compete with men, violence and limited support from fellow women.

The constraints to women political participation in elective politics identified in the survey correspond to earlier studies and existing literature showing that the traditional confinement of women within a largely patriarchal system limits their full participation in politics (Mlambo \& Kapingura, 2019).

The female respondents equally identified factors that remedy some of the existing constraints and improve the participation of women, especially in elective politics. These include economic empowerment of women (29.4\%), equal representation/parity of participation (23.6\%), elimination of all forms of discrimination against women $(17.6 \%)$, electoral reforms $(17.6 \%)$ and other incentives $(11.8 \%)$. The preponderance of respondents indicates that if the financial position of women candidates is improved and the electoral system reformed, women can compete favourably in elective positions even if some of the major forms of discrimination against women caused by socio-cultural and religious reasons persist. Parity of participation has been proposed by the Beijing Declaration and Platform for Action for Equality, Development and Peace, BPFA (1995) while the 'Justice Uwais' Electoral Reform Report' (2008) recommended, among others, an electoral system that would create more opportunities for relatively more women to compete for electoral positions. It proposed a combination of the First-Past-The-Past system and a modified proportional representation for legislative elections at the Federal, State and Local Governments. Such reforms will not only ensure greater inclusivity in politics in Nigeria but also reduce post-election tensions.

Table 14. Incentives for Greater Women Participation in Elective Politics

\begin{tabular}{|c|c|c|c|c|}
\hline Variables & Frequency & $\mathbf{\%}$ & Valid \% & Cumulative \% \\
\hline Electoral reform & 9 & 17.6 & 17.6 & 17.6 \\
\hline $\begin{array}{c}\text { Elimination of all forms of discrimination against } \\
\text { women }\end{array}$ & 9 & 17.6 & 17.6 & 35.2 \\
\hline Equal representation & 13 & 23.6 & 23.6 & 58.8 \\
\hline Economic empowerment for women & 15 & 29.4 & 29.4 & 88.2 \\
\hline Presence of incentives & 6 & 11.8 & 11.8 & 100 \\
\hline Total & 52 & 100 & 100 & \\
\hline
\end{tabular}

Source: Field Survey (2019)

\section{Views of Male Respondents}

Forty-eight (48) male respondents were asked a range of questions including their views on women participating in elective politics and their predisposition to allowing their wives to seek elective positions. As Table 15 shows, $70.8 \%$ of the respondents' express willingness to support their wives to contest elections. This position is further emphasized by some male politicians interviewed who supported radical reforms to the electoral process including the introduction of quotas for women. However, $20.8 \%$ are not disposed to encouraging their wives to seek elective offices while $8.4 \%$ were not certain they would support their wives in 
this regard. The very fact that women, in most parts of Nigeria, need the consent of their husbands to participate in politics confirms the patriarchal nature of the society where wives are answerable to men and require their consent to participate in politics. The subservience of women to men within the institution of marriage is justified by religious and cultural reasons(Mariachiara Di, 2014).

Table 15. Would you support/ encourage your wife to participate in elective politics?

\begin{tabular}{|l|l|c|c|c|c|}
\hline Variables & & Frequency & Percent & Valid Percent & Cumulative Percent \\
\hline \multirow{4}{*}{ Valid } & YES & 34 & 34.0 & 70.8 & 70.8 \\
\cline { 2 - 6 } & NO & 10 & 10.0 & 20.8 & 91.6 \\
\cline { 2 - 6 } & CAN'T SAY & 4 & 4.0 & 8.4 & 100.0 \\
\hline \multirow{3}{*}{ Total } & 48 & 48.0 & 100.0 & \\
\hline
\end{tabular}

Source: Field Survey (2019)

Male respondents were further asked to mention the conditions (if any) under which they would feel keener to allow their wives to seek elective positions. $50.0 \%$ of respondents identified improved security for women while $18.75 \%$ stated better funding incentives for women candidates as preconditions of allowing their wives to participate in politics. Other requirements include reform of the electoral process $(12.5 \%)$ and transparency in electoral processes and reduced corruption $(6.25 \%)$. It is well documented that the political environment in many developing countries like Nigeria is disproportionately harmful to women (Hunter \& Sargeant, 1993).

Table 16. Conditions under which men would allow their wives to seek elective positions

\begin{tabular}{|l|c|c|c|c|}
\hline Variables & Frequency & \% & Valid \% & Cumulative \% \\
\hline Equal rights for women & 6 & 12.5 & 12.5 & 12.5 \\
\hline Assurance of security & 24 & 50.0 & 50.0 & 62.5 \\
\hline Improved funding for women candidates & 9 & 18.75 & 18.75 & 81.25 \\
\hline Transparency \& reduced corruption & 3 & 6.25 & 6.25 & 87.5 \\
\hline Reform of the electoral process & 6 & 12.5 & 12.5 & 100.0 \\
\hline Total & 48 & 100 & 100 & \\
\hline
\end{tabular}

Source: Field Survey, (2019)

In addition, male respondents were asked their views on the relationship between women in the legislature and performance and whether the presence of more women in parliament can improve legislative output and consequently lead to national development. As Table 17 shows, $37.4 \%$ of the men surveyed hold the view that a legislature that has more women members would perform better and advance national development more aggressively for 
change(Devlin \& Elgie, 2008).

Table 17. Views of men on a female-dominated parliament in relation to performance

\begin{tabular}{|l|l|c|c|c|c|}
\hline Variables & & Frequency & Percent & Valid Percent & Cumulative Percent \\
\hline \multirow{3}{*}{ Valid } & YES & 18 & 18.0 & 37.4 & 36.7 \\
\cline { 2 - 6 } & NO & 15 & 15.0 & 31.3 & 67.3 \\
\cline { 2 - 6 } & CAN'T SAY & 15 & 15.0 & 31.3 & 100.0 \\
\hline \multicolumn{2}{r|}{ Total } & 48 & 48.0 & 100.0 & \\
\hline
\end{tabular}

Source: Field Survey (2019)

However, $31.3 \%$ of the respondents state that a women-dominated parliament would not perform optimally for various reasons including traditional gender roles and cultural limitations. Some of those interviewed who hold a similar view argued that there is no relationship between gender and performance. Several scholars have made the same arguments in the past. According to Fraser (2003, p. 36), "justice requires social arrangements that permit all members to participate in social interactions on a par with one another". Delving and Elgie (2008) also note that even though women may add new dimensions to policy agenda in parliament, their increased representation does not necessarily guarantee policy output on the one hand. On the other hand, $31.3 \%$ of the respondents were undecided on whether a legislature that is dominated by women would perform better than one dominated by men. However, recent studies show that women's leadership in political spheres can be socially beneficial such as reducing inequality, fostering cooperation across party and ethnic divides and prioritization of social issues such as health, education, welfare, etc. (Markham, 2013; Shapiro, 2002).

Male respondents were equally asked to identify hindrances to the effective participation of women in elective politics in Nigeria. Some of the constraints they identified reflect those already highlighted by female respondents. An orderly grouping arrangement of these constraints are as follows: socio-cultural/religious reasons $(40.7 \%)$, lack of funds $(21.4 \%)$, violence against women $(18.4 \%)$, gender inequality $(5.1 \%)$, nocturnal nature of political meetings $(4.2 \%)$, prejudice against women $(4.2 \%)$, poor educational background $(2.0 \%)$, lack of support from fellow women $(2.0 \%)$ and legal encumbrance $(2.0 \%)$.

Table 18. Constraints against Women's Participation in Elective Politics (men)

\begin{tabular}{|l|c|c|c|c|}
\hline Variables & Frequency & \multicolumn{1}{|l|}{$\%$} & Valid \% & Cumulative \% \\
\hline Lack of funds & 10 & 21.4 & 21.4 & 21.4 \\
\hline Violence against women & 9 & 18.4 & 18.4 & 39.8 \\
\hline Socio-cultural/religious reasons & 19 & 40.7 & 40.7 & 80.5 \\
\hline Education & 1 & 2.0 & 2.0 & 82.5 \\
\hline Gender inequality & 3 & 5.1 & 5.1 & 87.6 \\
\hline Lack of fellow women support & 1 & 2.0 & 2.0 & 89.6 \\
\hline Nocturnal nature of political meeting & 2 & 4.2 & 4.2 & 93.8 \\
\hline Prejudice & 2 & 4.2 & 4.2 & 98.0 \\
\hline
\end{tabular}




\begin{tabular}{|l|c|c|c|c|}
\hline Variables & Frequency & \% & Valid \% & Cumulative \% \\
\hline Legal encumbrance & 1 & 2.0 & 2.0 & 100.0 \\
\hline Total & 48 & 100 & 100 & \\
\hline
\end{tabular}

Source: Field Survey (2019)

All those surveyed indicate support for a reform of the electoral system in Nigeria to allow for greater women representation in the legislature. $85.5 \%$ support electoral reform to give women more seats in the legislature while $6.0 \%$ were against any such reform. The pervasive view, therefore, is that many respondents favour an electoral system that would give women more seats in the legislature as recommended by the Justice Uwais Electoral Reform Report (2008).

Table 19. Support for Greater Representation of Women in the Legislature

\begin{tabular}{|l|l|c|c|c|c|}
\hline Variables & Frequency & Percent & Valid Percent & $\begin{array}{c}\text { Cumulative } \\
\text { Percent }\end{array}$ \\
\hline \multirow{3}{*}{ Valid } & YES & 85 & 85.0 & 85.0 & 85.0 \\
\cline { 2 - 6 } & NO & 6 & 6.0 & 6.0 & 91.0 \\
\cline { 2 - 6 } & CAN'T & 9 & 9.0 & 9.0 & 100.0 \\
\cline { 2 - 6 } & SAY & & 100.0 & 100.0 & \\
\cline { 2 - 6 } & Total & 100 & & & \\
\hline
\end{tabular}

Source: Field Survey, (2019)

\section{The Impact of Women Legislative Representation in Nigeria's National Assembly}

One of the arguments for greater women participation in the legislature is that their presence in good number provides an opportunity to not only highlight the challenges facing women in society but also push for laws and policies to address them. According to Sanbonmatsu (2009), women are more empathetic and sympathetic to women-based issues such as family issues and tend to support or sponsor more women or family-related bills. This position is support by O'Brienand Rickne(2014)who argue that whereas "men dominate policy areas considered more prestigious, women may take leadership on what are considered 'social' issues."

In Nigeria, various legislations seeking to improve women's participation in politics and eliminate customs and practices that discriminate against women in relation to access to resources (e.g., land) have mostly been sponsored by female legislators. Others have focused on improving social services (education, health, etc.) and the welfare of women through the provision of gender and family friendly-social infrastructure. Some of these are shown below. 
Box 1: Some Gender-Related Bills Introduced in the National Assembly since 1999

- Circumcision of Women (Prohibition) Bill, 2000

- Maternal and Child Welfare Health Services Procedure etc. Bill, 2001

- Children's Rights Bill, 2002

- Uniform Legislation on the Succession and Inheritance of Intestate Property in Nigeria Bill (2002)

- A Bill for an Act to Ratify and Enforce the Treaty on the Protocol to Prevent, Suppress and Punish Trafficking in Persons, especially Women and Children, Supplementing the United Nations Convention Against Transitional Organised Crimes, 2003

- National Council for Widows, Dependent Children and Orphans (Establishment, Special Provisions, etc.) Bill, 2007

- Abolition of Discrimination Against Women Bill, 2008

- National Hospital for Women and Children Act (Amendment) Bill, 2008

- Gender Equal Opportunities, Abuse and Administration Bill, 2010

- Women and Girls Advancement Bill, 2012

- Affirmative Action (Equal Opportunity for Women) Bill, 2012

- Property Right of Spouses Bill, 2013

- Gender and Equal Opportunities Bill, 2016

- Sexual Harassment in Tertiary Educational Institution Bill, 2016

Source: Author's Compilation, 2018

However, an analysis of the gender-based draft legislations proposed by women in Nigeria's $7^{\text {th }}$ and $8^{\text {th }}$ Assemblies shows that several women and youth-related bills have failed to pass Second Reading and those that were considered and reported out of Committees and laid at plenary were not successfully passed as shown in Table 20. The bulk of the Bills were either never reported or lapsed at the end of the respective assemblies as Table 20 shows.

Table 20. Gender-related Bills in the House of Representatives (7th\& 8th Assemblies)

\begin{tabular}{|c|c|c|c|}
\hline $\mathbf{S} / \mathbf{N}$ & TITLE & STATUS & REMARKS \\
\hline \multicolumn{4}{|c|}{$7^{\mathrm{TH}}$ ASSEMBLY } \\
\hline 1. & $\begin{array}{l}\text { (HB. 249) Anti-Violence against Women and } \\
\text { Children Bill, } 2012\end{array}$ & $\begin{array}{l}\text { Introduced } \\
19 / 4 / 2012\end{array}$ & Lapsed \\
\hline 2. & $\begin{array}{l}\text { (HB. 350) Affirmative Action (Equal } \\
\text { Opportunity for Women) Bill, } 2012\end{array}$ & $\begin{array}{l}\text { Introduced } \\
9 / 10 / 2012\end{array}$ & Lapsed \\
\hline 3. & $\begin{array}{l}\text { (HB. 388) Women and Girls Advancement } \\
\text { Bill, } 2012\end{array}$ & $\begin{array}{l}\text { Introduced } \\
6 / 11 / 2012\end{array}$ & Lapsed \\
\hline 4. & $\begin{array}{l}\text { (HB. 692) Maryam Babangida National } \\
\text { Centre for Women Development } \\
\text { (Establishment) Bill, } 2014\end{array}$ & $\begin{array}{l}\text { Committee of the Whole } \\
3 / 3 / 2015\end{array}$ & Lapsed \\
\hline 5. & (HB. 717) National Hospital for & Passed by both Houses & Lapsed \\
\hline
\end{tabular}




\begin{tabular}{|c|c|c|c|}
\hline $\mathbf{S} / \mathbf{N}$ & TITLE & STATUS & REMARKS \\
\hline & $\begin{array}{l}\text { Women and Children, Abuja (Establishment, } \\
\text { etc.) Act (Amendment) Bill, } 2014\end{array}$ & $23 / 4 / 2015$ & \\
\hline \multicolumn{4}{|c|}{$8^{\mathrm{TH}}$ ASSEMBLY } \\
\hline 6. & $\begin{array}{l}\text { HB. } 124 \text { National Council for Widows, } \\
\text { Dependent Children and Orphans } \\
\text { (Establishment, Special Provisions, etc.) }\end{array}$ & $\begin{array}{l}\text { Referred to the Committee on } \\
\text { Women Affairs and Social } \\
\text { Development } \\
\text { 2/3/2017 }\end{array}$ & Not Reported \\
\hline 7. & $\begin{array}{l}\text { HB. } 455 \text { Nigerian Children Trust Fund Act } \\
\text { (Amendment) Bill, } 2016\end{array}$ & $\begin{array}{l}\text { Laid on Table } \\
20 / 12 / 2017\end{array}$ & $\begin{array}{c}\text { Awaiting } \\
\text { Consideration }\end{array}$ \\
\hline 8. & $\begin{array}{l}\text { HB. } 1156 \text { Family Economic Advancement } \\
\text { Programme (Establishment, Etc.) Act } \\
\text { (Repeal) Bill, } 2017\end{array}$ & $\begin{array}{l}\text { Referred to the Committee on } \\
\text { Women Affairs and Social } \\
\text { Development } \\
24 / 10 / 2017\end{array}$ & Not Reported \\
\hline 9. & $\begin{array}{l}\text { HB. } 1273 \text { Nigerian Children Trust Fund Act } \\
\text { (Amendment) Bill, } 2018\end{array}$ & $\begin{array}{l}\text { Referred to the Committee on } \\
\text { Women Affairs and Social } \\
\text { Development } \\
\text { 25/1/2018 }\end{array}$ & Not Reported \\
\hline 10. & $\begin{array}{l}\text { HB. } 1297 \text { National Centre for Child } \\
\text { Development (Establishment) Bill, } 2018\end{array}$ & $\begin{array}{l}\text { Referred to the Committee on } \\
\text { Women Affairs and Social } \\
\text { Development } \\
\text { 12/7/2018 }\end{array}$ & Not Reported \\
\hline 11. & $\begin{array}{l}\text { HB. } 1500 \text { National Centre for Women } \\
\begin{array}{l}\text { Development Act } \quad \text { (Repeal } \\
\text { Re-Enactment) Bill, } 2018\end{array}\end{array}$ & $\begin{array}{l}\text { Introduced } \\
3 / 7 / 2018\end{array}$ & $\begin{array}{l}\text { Awaiting } \\
\text { Second } \\
\text { Reading }\end{array}$ \\
\hline 12. & $\begin{array}{l}\text { HB. } 1594 \text { Women Participation in Elections } \\
\text { Support Bill, } 2018\end{array}$ & $\begin{array}{l}\text { Debate Adjourned } \\
24 / 1 / 2019\end{array}$ & $\begin{array}{l}\text { Awaiting } \\
\text { Second } \\
\text { Reading }\end{array}$ \\
\hline
\end{tabular}

Source: Rules and Business Committee of the House of Representatives, Nigeria, 2019

In general, numerous gender-related bills have been introduced in the National Assembly in the last two decades. However, only a few of these draft legislations successfully passed through all the legislative processes to assent. These include the Violence against Persons (Prohibition) Act, 2015 (VAAP); Trafficking in Persons (Prohibition) Enforcement and Administration Act, 2015; Child Rights Act, 2003; and the Administration of Criminal Justice Act (ACJA), 2015.

Despite chairing some Standing Committees in the $8^{\text {th }}$ Assembly, women legislators were not able to significantly introduce and successfully pass more gender-specific legislations. This has been blamed on existing stereotypes towards women and women-related issues, suspicion on the part of some legislators on the implication of women empowerment on the balance of power, lack of interest on the part of legislations, greater focus on other more "lucrative" bills and absence of bi-partisan and inter-chamber agreement on critical gender-based legislations. 
Others interviewed attributed the limited success of such bills to include the perception by some legislators that they are largely sponsored by foreign interests including non-governmental organisations, lack of sufficient consultation before the bills were introduced on the floor of the house and the supposedly "combative" posture assumed by women legislators who sponsored them.

\section{Conclusion}

This study focuses on women and legislative representation with a specific focus on the National Assembly. It examines the trends, effects, challenges and prospects of women's representation in Nigeria's National Assembly. The underpinning assumption of the study is the principle of parity of participation which, according to the IPU, infers that a representative parliament should allow the different experiences of both men and women representing constituents to direct policy priorities and legislative output to determine the social, economic and political future of society. The Nigerian National Assembly is a bicameral legislature, established under section 4 of the Constitution of the Federal Republic of Nigeria 1999 (as amended). Moreover, Sections 15 (2) and 42 of the Constitution further makes provision for national integration and guarantees rights to freedom from discriminations for all citizens; irrespective of origin, sex, religion, status, political opinion etc.

A review of the global trend in women parliamentary representation shows that although there has been significant improvement in the last two decades even in African countries, however, not much progress has been made in Nigeria where women representation in the legislature, especially at the National Assembly, has not changed significantly since 1999.

Results from the study shows that majority of female respondents indicated that $76.5 \%$ of female respondents show an active interest in politics. However, of these, $86.3 \%$ have not vied for a political position; only $13.7 \%$ have. Furthermore, $48 \%$ of the female respondents indicated an interest in elective positions while $30 \%$ were uncertain. This signifies that given a favourable political environment, women are likely to engage more and contest for elective positions. Some of the identified constraints militating against women participation in politics include prevailing gender stereotypes, cultural/religious reasons, violence, lack of finance and restrictive party structures and processes amongst others.

In view of the findings of this study, several recommendations can be offered towards improving women representation and participation in political and governance processes. Due to the long history of discrimination and exclusion based on social, religious and cultural reasons, deliberate policies and laws are needed to address the imbalance in women representation, especially in elective positions. The use of quota systems in the legislature to improve women representation will go a long way in this regard. As shown by the experience of several countries, enshrined and legally protected quota systems ensure that women are adequately represented in parliaments. The National Gender Policy, which prescribes $30 \%$ of all elective and appointive positions to women, should be given the enabling legal framework to ensure compliance. 


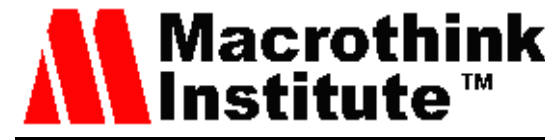

Journal of Public Administration and Governance ISSN 2161-7104 2021, Vol. 11, No. 2

Equally important is the elimination of structural barriers that limit women participation in political and governance processes. Deliberate policies and legislations should target women quotas and affirmative action across democratic institutions especially political parties that present candidates for election. Such laws and policies could target reserving some seats and positions to women candidates, reducing the cost of political participation for women and including women in the leadership structures of political parties. Given the challenges posed by the limited financial capacity of most women, such measures would stimulate a greater interest to participate in politics and seek elective positions. Given that political parties receive funding from government agencies, development partners and NGOs, special funding incentives can be developed for women candidates.

Reform of the electoral process is equally critical to improving women participation in political processes in Nigeria. Some aspects of the Justice Uwais Report on Electoral Reform in Nigeria can be adopted. The recommendation on the adoption of a hybrid electoral system, for instance, can ensure that more women participate in elections and occupy elective positions. Other measures include the use of stringent and punitive measures against sponsors and perpetrators of electoral violence, which often hamper women participation.

Finally, given the preponderance of stereotypes ascribed to social, religious and cultural reasons, sustained and systematic gender education (in formal, educational and informal institutions) should be prioritised and implemented by the government. School curricula at primary and post-primary levels should include aspects of gender education. Similarly, public education and sensitization on gender should be institutionalised through the traditional and social media outlets as well as the promotion of such education and sensitization in both religious and traditional institutions.

\section{References}

Agishi, T. V. (2014). Women participation in party politics in Nigeria: Challenges and the way forward. Arabian Journal of Business and Management Review, 2(4). https://doi.org/10.12816/0011586

Ballington, J., \& Karam, A. (Eds.). (2005). Women in Parliament: Beyond Numbers. Sweden: International Institute for Democracy and Electoral Assistance.

Devlin, C., \& Elgie, R. (2008). The Effect of Increased Women's Representation in Parliament: The Case of Rwanda. Parliamentary Affairs, 61(2), 237-254. https://doi.org/10.1093/pa/gsn007

Dim, E. E., \& Asomah, J. Y. (2019). Sociodemographic Predictors of Political participation among women in Nigeria: Insights from Afrobarometer 2015 Data. Journal of International Women's Studies, 20(2), 91-105.

Ezeani, O. E., \& Ezeibe, C. C. (2013). Gender and democracy in Nigeria: a critical analysis of women participation in the federal legislature. Journal of Gender, Information and Development in Africa (JGIDA), 2(1-2). 


\section{Macrothink}

Journal of Public Administration and Governance ISSN 2161-7104 2021, Vol. 11, No. 2

Fraser, N. (2003). Social Justice in the Age of Identity Politics: Redistribution, Recognition, and Participation. In N. Fraser \& A. Honneth (Eds.), Redistribution or Recognition? A Political Philosophical Exchange. London: Verso.

Haider-Markel, D. P. (2010). Out and Running Gay and Lesbian Candidates, Elections, and Policy Representation: Georgetown University Press.

Hamalai, L. (2014). Continuity and Change in Nigeria's Elections: A Collection of Essays. In L. Hamalai (Ed.), Women Leadership as a Change Factor: Fostering Gender Balance in Politics and Governance in Nigeria (pp. 66-82). Abuja: National Institute of Legislative Studies.

Hartzell, C. A., \& Hoddie, M. (2003). Institutionalizing Peace: Power Sharing and Post-Civil War Conflict Management. American Journal of Political Science, 47(2), 318-332. https://doi.org/10.1111/1540-5907.00022

Hunter, J. D., \& Sargeant, K. H. (1993). Religion, Women, and the Transformation of Public Culture. Social Research, 60(3), 545-570.

Inter-Parliamentary Union. (1998). Democracy: Its Principles and Achievement. Geneva: IPU.

IPU. (2016). Women in parliament in 2016: The year in review. Retrieved from Geneva: http://archive.ipu.org/pdf/publications/WIP2016-e.pdf

Karam, A., \& Lovenduski, J. (2005). Women in Parliament: Making a Difference Women in Politics: Women in Parliament: Beyond the Numbers: International IDEA.

Lovenduski, J., \& Norris, P. (2003). Westminster Women: The Politics of Presence. Political Studies, 51(1), 84-102. https://doi.org/10.1111/1467-9248.00414

Mariachiara Di, C. (2014). Women, marginalization, and vulnerability: introduction. Genus, 70(2-3), 1-6.

Markham, S. (2013) Women as Agents of Change: Having Voice in Society and Influencing Policy. Women's Voice, Agency, and Participation Research Series: The World Bank.

Milbrath, L. W. (1965). Political participation: How and why people get involved in politics. Chicago: Rand Mc Nally \& Co.

Mlambo, C., \& Kapingura, F. (2019). Factors influencing women political participation: The case of the SADC region. Cogent Social Sciences, 5(1), 1681048. https://doi.org/10.1080/23311886.2019.1681048

NDI. (2010). Women as Agents of Change: Advancing the Role of Women in Politics and Civil Society Statement by Kenneth Wollack, President, National Democratic Institute before the House Committee on Foreign Affairs Subcommittee on International Organizations, Human Rights and Oversight. Washington: National Democratic Institute. 
Ndlovu, S., \& Mutale, S. B. (2013). Emerging Trends in Women's Participation in Politics in Africa. American Journal of Contemporary Research, 3(11).

Norris, P. (2008). Driving Democracy: Do Power-sharing Institutions Work? Cambridge: Cambridge University Press. https://doi.org/10.1017/CBO9780511790614

Norris, P., \& Inglehart, R. (2001). Women and Democracy: Cultural Obstacles to Equal Representation. Journal of Democracy, 12(3), 126-140. https://doi.org/10.1353/jod.2001.0054

Nwabunkeonye, U. P. (2014). Challenges to Women Active Participation in Politics in Nigeria. Sociology and Anthropology, 2(7), 286-288.

O’Brien, D. Z., \& Rickne, J. (2014). Gender Quotas and Women's Political Leadership. https://doi.org/10.2139/ssrn.2498108

Obiyan, A. S., \& Akindele, S. T. (2002). The Federal Character Principle and Gender Representation in Nigeria. Journal of Social Sciences, 6(4), 241-246. https://doi.org/10.1080/09718923.2002.11892352

Oluyemi, O. (2016). Monitoring Participation of Women in Politics in Nigeria. Abuja: National Bureau of Statistics.

Pande, R., \& Ford, D. (2011). Gender Quotas and Female Leadership: A Review. Retrieved from

http://www.hks.harvard.edu/fs/rpande/papers/Gender\%20Quotas\%20-\%20April\%202011.pdf

Para-Mallam, F. J. (2010). Promoting gender equality in the context of Nigerian cultural and religious expression: beyond increasing female access to education. Compare A Journal of Comparative and International Education, 40(4), 459-477. https://doi.org/10.1080/03057925.2010.490370

Paxton, P., \& Kunovich, S. (2003). Women's Political Representation: The Importance of Ideology*. Social Forces, 82(1), 87-113. https://doi.org/10.1353/sof.2003.0105

Paxton, P., Kunovich, S., \& Hughes, M. M. (2007). Gender in Politics. Annual Review of Sociology, 33(1), 263-284. https://doi.org/10.1146/annurev.soc.33.040406.131651

PLAC. (2018). Women's Political Representation in Nigeria: Why progress is slow and what can be done to fast-track it. Retrieved from Abuja:

Reynolds, A. (2011). Women in the Legislatures and Executives of the World: Knocking at the Highest Glass Ceiling. World Politics, 51(4), 547-572. https://doi.org/10.1017/S0043887100009254

Reynolds, A. (2013). Representation and Rights: The Impact of LGBT Legislators in Comparative Perspective. American Political Science Review, 1-16.

Rosenthal, C. S. (2001). Gender Styles in Legislative Committees. Women \& Politics, 21(2), 21-46. https://doi.org/10.1300/J014v21n02_02 


\section{Macrothink}

Journal of Public Administration and Governance ISSN 2161-7104 2021, Vol. 11, No. 2

Sanbonmatsu, K., Carroll, S. J., \& Walsh, D. (2009). Poised to Run: Women's Pathways to the State Legislatures. New Brunswick, NJ: Centre for American Women and Politics, Eagleton Institute of Politics, Rutgers University.

Shapiro, R. Y. (2002). [The Private Roots of Public Action: Gender, Equality, and Political Participation, Nancy Burns, Kay Lehman Schlozman, Sidney Verba]. Political Science Quarterly, 117(3), 497-499. https://doi.org/10.2307/798270

Shevchenko, I. (2002). Who Cares About Women's Problems? Female legislators in the 1995 and 1999 Russian State Dumas. Europe-Asia Studies, 54(8), 1208. https://doi.org/10.1080/0966813022000025853

Shola Omotola, J. (2012). Democratization and Citizenship: The Gender Dimensions of Political Representation in Nigeria. In B. Wejnert (Ed.), Linking Environment, Democracy and Gender (Vol. 20, pp. 1-22): Emerald Group Publishing Limited. https://doi.org/10.1108/S0895-9935(2012)0000020003

Tremblay, M. (Ed.) (2008). Women and Legislative Representation Electoral Systems, Political Parties, and Sex Quotas (1 ed.): Palgrave Macmillan US.

Willis, D. (2014, Aug. 12, 2014). Gender Gap. Does the prospect of Running for Office Discourage women? New York Times. Retrieved from https://www.nytimes.com/2014/08/13/upshot/does-the-prospect-of-running-for-office-discour age-women.html

\section{Copyright Disclaimer}

Copyright for this article is retained by the author(s), with first publication rights granted to the journal.

This is an open-access article distributed under the terms and conditions of the Creative Commons Attribution license (http://creativecommons.org/licenses/by/4.0/). 